\title{
表土移植工法により造成された皇居東御苑の 雑木林土壤の理化学的性質の変化
}

\author{
高橋輝昌 $^{1} \cdot$ 生原喜久雄 ${ }^{2} \cdot$ 峰松浩彦 ${ }^{2}$
}

\begin{abstract}
摘要 : 皇居東御苑二の丸に雑木林を造成する際に, 森林土壤の表層部をできるだけ攪乱せずに造成緑地に移植す る表土移植工法が採用された。二の丸雑木林に移植された表層土壤が，造成後約 10 年間でどのように変化した のかを検討するために, 土壤の理化学的性質を二の丸雑木林と表土採取地の雑木林（武蔵野林）で比較した。二 の丸雑木林土䁃は武蔵野林土壤と比べて $\mathrm{pH}$ が高く, 炭素および窒素濃度が低く, 交換性塩基濃度が高かった。 これらの原因の一つとして造成地周囲からの粉塵の影響が考えられた。二の丸雑木林土壌の化学的性質の変化は 植生や土壤生物の組成・数に影響を及ぼすと考えられ，さらに調查していく必要がある。

キーワード : 都市緑地, 土壤の化学的性質, 雑木林, 土壌の理学的性質, 植栽基盤, 表土移植工法
\end{abstract}

Takahashi, Terumasa, Haibara, Kikuo and Minematsu, Hirohiko : Changes in physical and chemical characteristics of soil of coppice forest made using transference intact surface soil in the Higashi Imperial Gardens

Abstract: Transference intact surface soil is the new method which transfer forest surface soil without disturbance as much as possible for preparation of artificial urban open space. We investigated physical and chemical characteristics of soils in coppice forest which was made using transference intact surface soil on Higashi Imperial Gardens (T) about 10 years ago and natural coppice forest $(\mathrm{N})$ which established near the collecting area of surface soil for the transference and compared these characteristics between $\mathrm{T}$ and $\mathrm{N}$ to examine the changes in $\mathrm{T}$ soil for about 10 years. Thickness of transferred soil on $\mathrm{T}$ soil was approximatery $10 \mathrm{~cm}$. The soil acidities of $\mathrm{T}$ soils transferred were higher than $\mathrm{N}$ soils. The carbon and nitrogen concentrations of $\mathrm{T}$ soils were considerably lower than $\mathrm{N}$ soils. The exchangeable bases concentrations of $\mathrm{T}$ soils shows tendency to exceed them of $\mathrm{N}$ soils. It seemed that soil organic matter in $\mathrm{T}$ were decreased. It seemed that the transferred soil on $\mathrm{T}$ were affected by deposition and so on. Because it is expected that those changes in the characteristics of $\mathrm{T}$ soil affect vegetations and soil organisms, further investigations concerning them are needed.

Key words: artificial urban open space, chemical characteristics of soil, coppice forest, physical characteristics of soil, planting ground, transference intact surface soil

\section{1.はじめに}

都市緑地の役割として，ヒートアイランド現象・騒音・大 気污染等の緩和機能が古くから認識されている。近年，都市 化の進行や都市住民の価值観の変化・多様化に伴い，都市緑 地に対して求められる新たな役割として，多様性と固有性を 持った生態系の保全・復元がある。このため, 各地に自然環 境の保全や復元を目的とした多自然型河川, ビオトープ, 都 市自然公園等の多様な緑地の造成が試みられている7 ような緑地において, 植生の早期繁茂と健全な生育を図り, 維持するためには植栽基盤（土壤）を適切な状態に造成・維 持することが不可欠である。

植裁基盤の工法には, 造成する緑地の形態, 目的, 土壤の 性質等に応じて様々なものが考案されている5)。

人工緑地の造成に広く用いられている, 重機による地面の 踏み固めや表層土畩の除去を伴う工法は, 土壌の理化学的性 質を悪化させ，植物の生育や回復にとって好ましくないこと
が指摘されている

森林の表層土㙵（表土）は腐植物質を多く含むことから， 膨軟で高い養分保持能や有機物の分解能をもち，植物の生育 に適している。このような表土の性質に着目した，緑地の造 成に際して造成予定地の表土をあらかじめ保存し，植栽地に 撒き出す工法である「表土保全」は，我が国では昭和 40 年 代から行われ始めた ${ }^{2)}$ 。表土保全の効果として, 植栽樹木の 生育の向上が挙げられている ${ }^{10)}$ 。一般に, 表土保全工法では 表土採取にブルドーザーを用い，採取した表土を $3 \sim 6$ 年堆 積させるため，採取した土壤の攪乱・構造の破壊や下層土の 混入は避けられない ${ }^{10,16)}$ 。このため, 本来表土が持つ肥沃さ が植物の生育に十分に利用されない欠点を持つ。表土には多 くの場合，埋土種子が含まれていることから，道路の法面緑 化の際, 早期に植生を回復させる目的で表土保全が用いられ ることがある2)。しかし，表土を撒き出す際に埋土種子の上 に多量の土壤が堆積すると, 埋土種子の発芽が抑制される。 近年, 森林表土を利用する新たな工法として, 森林表土を

\footnotetext{
${ }^{1}$ 千葉大学園芸学部, Fac. of Hort., Chiba Univ.

${ }^{2}$ 東京農工大学農学部, Fac. of Agric., Tokyo Univ. of Agric. and Technol.
} 
できるだけ攪乱せずに造成緑地に移植する「表土移植工法」 が試みられ，表土を採取した森林における主要な構成植物種 が根や埋土種子として運ばれ，移植後も高い割合で維持され ていることが報告されている8)。この表土移植工法は森林土 壌の最も肥沃な部分のみを土壌構造をできるだけこわさず移 植するために, 土壤の理化学的性質の維持が期待される。

そこで, 本研究では表土移植工法の有効性について検討す る一環として, およそ 10 年前に武蔵野の雑木林の表土を表 土移植工法で移植して新しく造成された雑木林の土壌と, 表 土を採取した付近の雑木林の土壌の理化学的性質を比較し, 表土移植工法で移植された土壤の変化を明らかにすることを 目的とした。

\section{2. 調査地の概況}

調查地は東京都千代田区の皇居東御苑二の丸に造成された面 積 $8,200 \mathrm{~m}^{2}$ の雑木林 (二の丸雑木林) と神奈川県相模原市 にある「こもれびの森」の雑木林 (武蔵野林) である（図1)。

二の丸雑木林は武蔵野の雑木林の復元を目的として, 芝生 広場であったところに，1982 年から 1985 年にかけて以下に

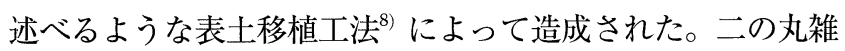
木林の表土には東京都町田市，神奈川県相模原市のコナラ， クヌギ, イイギリ, イヌシデ等が高木層を占める雑木林で $10 \mathrm{~cm}$ 程度までの梁さから, そこにある植物の根も含めてで きるだけ構造を保ったまま採取し, 浅い木箱（トロ箱）に入 れて搬出・運搬したものを用いた。二の丸雑木林の造成予定 地の在来地盤を $50 \mathrm{~cm}$ の深さまで耕耘し, 赤土（火山灰土 䗙の心土）を造成前後の地形に応じて $0 \sim 80 \mathrm{~cm}$ 盛土した上 に町田市, 相模原市で採取した雑木林の表土を構造をできる だけ保ったまま $10 \mathrm{~cm}$ 程度の厚さに移植した。
二の丸雑木林に移植した樹木は主として栃木県内で採取さ れた武蔵野の雑木林を代表する落葉広葉樹（コナラ，ヤマザ クラ，エゴノキ，クヌギ等）である。また，町田市と相模原 市で採取された地被類も土壤ごと移植された。これらの移植 は 1982 年 3 月と 1983 年 3 月に行われた。植栽に際して施肥 は行われていない。1996 年には二の丸雑木林内で植物が 270 種確認され, 植栽された植物 (約 100 種類) の他に, 移植し た表土中の根や埋土種子などからも多く発生している ${ }^{8)}$ 。

武蔵野林は二の丸雑木林への移植土壌採取地域に隣接して おり, 現在, 面積 73 ha の雑木林として管理されている。

\section{3. 調査方法}

1996 年 9 月に二の丸雑木林内の 3 力所（断面 1 ～ 3 , 二の 丸土壤), 武蔵野林内 22 力所 (断面 4, 5, 武蔵野土壤) （図-1）で土壌断面調査を行い, 理化学的性質を調べるため の試料の採取を層位ごとに行った。いずれの断面でも $70 \mathrm{~cm}$ 程度までの土壤試料を採取したが，断面 $1 ， 2$ については土

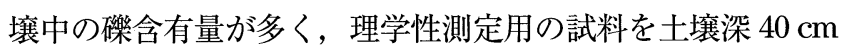
までしか採取できなかった。採取した試料について，以下の 測定を行った。

三相組成を $100 \mathrm{ml}$ 採土円筒で採取した試料について，土 壤三相計を用いて測定した。土㙵の透水性を $400 \mathrm{ml}$ 採土円 筒で採取した試料について, 真下式透水試験装置 ${ }^{9)}$ を用いて 測定した。 $\mathrm{pH}\left(\mathrm{H}_{2} \mathrm{O}\right)$ (生土 : $\left.\mathrm{H}_{2} \mathrm{O}=1: 2.5\right)$ をガラス電極法 で, 全炭素 (C), 全窒素 $(\mathrm{N})$ 濃度を $\mathrm{CN}$ コーダー法で, 交 換性カリウム $(\mathrm{K})$, カルシウム $(\mathrm{Ca})$, マグネシウム $(\mathrm{Mg})$ 濃度を $1 \mathrm{~N}-\mathrm{CH}_{3} \mathrm{COONH}_{4}$ による抽出後, 原子吸光法でそれぞ れ測定した ${ }^{3)}$ 。

1997 年 9 月に二の丸雑木林の移植土壤の $\mathrm{pH}\left(\mathrm{H}_{2} \mathrm{O}\right)$ 分布を 調查するために，二の丸雑木林全体を $10 \mathrm{~m}$ メッシュに区切

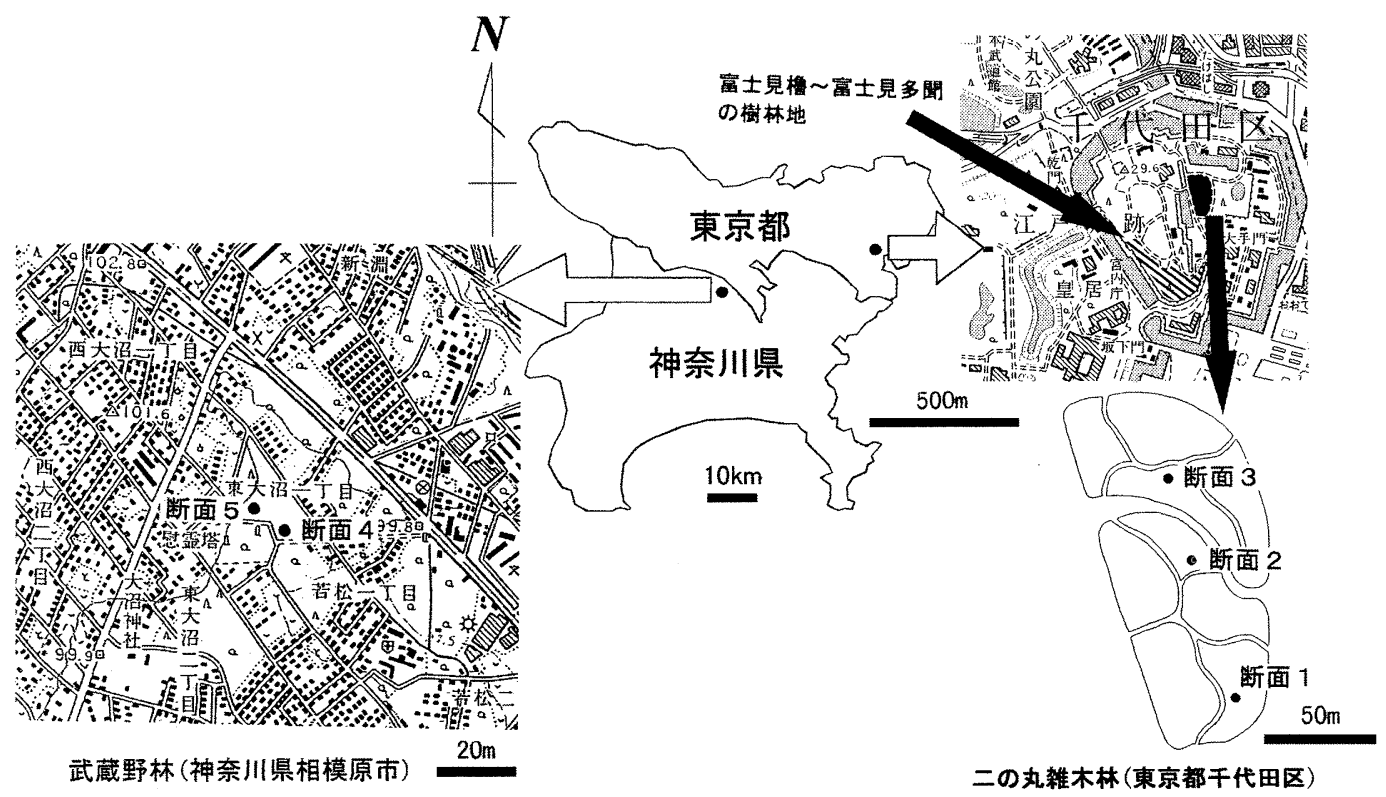

図-1 調查地の位置

Fig. 1 Location of study sites. 
り, 合計 89 地点から土壌深 $0 \sim 10 \mathrm{~cm}$ の土袞を採取し, $\mathrm{pH}$ $\left(\mathrm{H}_{2} \mathrm{O}\right)$ を測定した。また，二の丸雑木林の南西に約 $300 \mathrm{~m}$ 離れた富士見櫓〜富士見多聞の樹林地内（図-1）で 20 地点 から土壌深 0 〜 $10 \mathrm{~cm}$ の土壤を採取し, $\mathrm{pH}\left(\mathrm{H}_{2} \mathrm{O}\right)$ を测定し た。富士見櫓〜富士見多聞の樹林地は 1966 年 11 月から 1967 年 3 月にかけて造成され，ほとんど人手を加えられて いない。

\section{4. 結果と考察}

\section{1 土壤断面}

土壤断面調査の結果を表-1 に示す。土色をみると，断面 1 では土壌深 $70 \mathrm{~cm}$ まで暗褐色であり， $70 \mathrm{~cm}$ 以深では褐色で あったのに対して，断面 2 と 3 では土袞深 $7 \mathrm{~cm}$ までの移植 された部分が極暗褐色〜暗褐色，それより下層が褐色，さら にその下層が黒褐色〜暗褐色であった。二の丸土壤の断面で は雑木林造成に伴って形成された，土壤表層から下層にかけ ての移植土壌 $(0 \sim 10 \mathrm{~cm})$-赤土の盛土 $(20 \sim 70 \mathrm{~cm})$-造成 前の在来土壤という構造が造成後 10 年以上経っても保たれ ていた。武蔵野土壌は，断面 4，5 ともにいずれの層でも黒 褐色の典型的な黒ボク土 (火山灰土壤) であった。二の丸土 壤の水湿状態は，断面 1 では全ての層で潤であったが，断面 2 と 3 では移植土壤 $(0 \sim 7 \mathrm{~cm})$ が潤, それより下層が乾で あった。武蔵野土䁃の水湿状態は, 断面 4,5 ともに全ての 層で閏であった。水湿状態の潤と乾は, 土壌水の張力特性

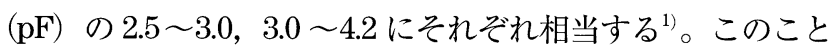
から，二の丸雑木林の移植土壌は植物の生育に適度な水分を 保持している。しかし，移植土壤より下層の土壤水分は毛管 連絡切断水分点（pF 3.0）以下の植物に利用されにくい状態 にある。土性はいずれの土䁃でも微砂質壤土であった。堅密 度には二の丸土袞と武蔵野土壤で明らかな違いはみられな かった。

4.2 土壤の理学的性質

各土壌断面における土䁃深 $0 \sim 10 \mathrm{~cm}$ の三相分布を図-2 に示す。二の丸雑木林の移植土壤（土壤深 0 〜 $\mathrm{cm}$ または $10 \mathrm{~cm}$ ) の固相率は 16 ～ $25 \%$ であり，武蔵野林（土壌深 0 ～ $10 \mathrm{~cm})$ の固相率 $(25,29 \%)$ に比べて低かった。また，土
壤深 $0 \sim 10 \mathrm{~cm}$ の液相率は二の丸雑木林（移植土壤）で 30 〜34\%であるのに対して，武蔵野林では $36,41 \%$ であった。 このように, 武蔵野林から二の丸雑木林への表層土壤の移植 に伴い多少の土壌構造の破壊がおこり, 土壤孔隙量が増加し ている。

土壤の透水速度を図-3に示す。造成緑地の植裁基盤の透 水速度は $10^{-3} \sim 10^{-4} \mathrm{~cm} \mathrm{~s}^{-1}$ で「不良」, また, $10^{-4} \mathrm{~cm} \mathrm{~s}^{-1}$ 以下 で「極不良」と評価される ${ }^{14)}$ 。本調査地の透水速度はいずれ の断面, 土壤深でも $4.0 \times 10^{-3} \sim 2.2 \times 10^{-2} \mathrm{~cm} \mathrm{~s}^{-1}$ 以上であり, 樹木の生育に適した範囲であった。二の丸雑木林の移植土壤 の透水速度は移植後約 10 年経っても武蔵野林の表層土と同 様の $1.4 〜 2.0 \times 10^{-2} \mathrm{~cm} \mathrm{~s}^{-1}$ の範囲に保たれていた。

4.3 土㙵の化学的性質

各調査地の土壤 $\mathrm{pH}\left(\mathrm{H}_{2} \mathrm{O}\right)$ を図-4 に示す。どの断面でも土 壤 $\mathrm{pH}\left(\mathrm{H}_{2} \mathrm{O}\right)$ は表層部で低くなる傾向にあった。二の丸雑木

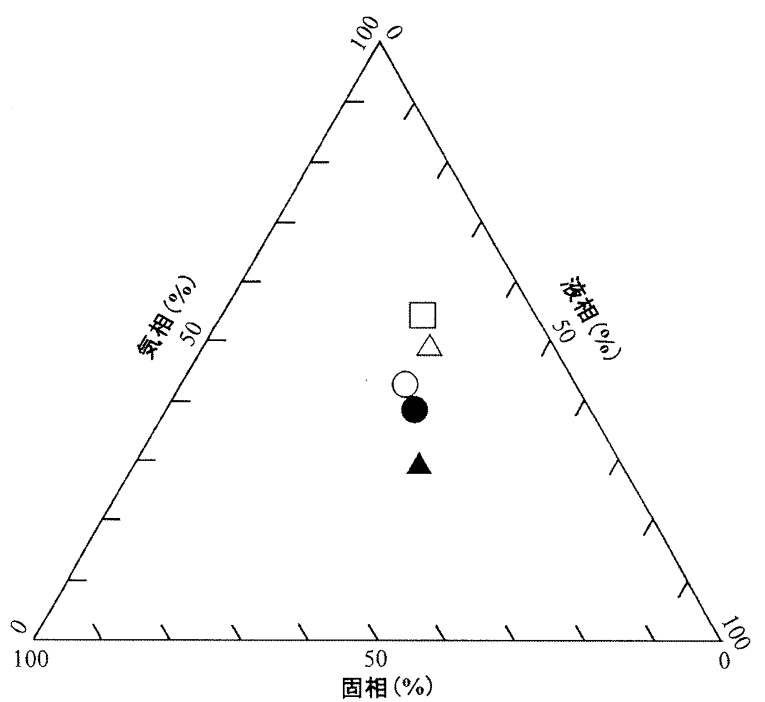

図-2 土壤深 $0 \sim 10 \mathrm{~cm}$ の三相分布

$\bigcirc$ : 断面 $1, \triangle$ : 断面 $2, \square$ : 断面 $3, \bigcirc$ : 断面 $4, \triangle$ : 断 面 5

Fig. 2 Three-phase distributions of soil 0-10 $\mathrm{cm}$ depth.

$\bigcirc$ : Profile $1, \triangle$ : Profile $2, \square$ : Profile $3, \bigcirc$ : Profile 4 , $\Delta$ : Profile 5.

表-1 土壤断面調査の結果

Table 1 Soil profiles

\begin{tabular}{|c|c|c|c|c|c|c|}
\hline 調查地 & 断面番号 & 土畩深 $(\mathrm{cm})$ & 土色 & 腐植 & 水湿状態 & 堅密度 \\
\hline 皇居東御苑二の丸雑木林 & 1 & $0 \sim 70$ & 7.5YR3/3（暗褐色） & 含む & 潤 & 軟 \\
\hline \multirow{7}{*}{ (二の丸土畩) } & & 70 以深 & 7.5YR4/4（褐色） & 含む & 潤 & 堅 \\
\hline & 2 & $0 \sim 7$ & 7.5YR2/3（極暗褐色） & 富む & 潤 & しょう〜軟 \\
\hline & & $7 \sim 65$ & 7.5YR4/4（褐色） & 含む & 乾 & 軟～堅 \\
\hline & & 65 以深 & 7.5YR3/2（黒褐色） & 富む & 乾 & 堅 \\
\hline & 3 & $0 \sim 7$ & 7.5YR3/3（暗褐色） & 富む & 潤 & しょう〜軟 \\
\hline & & $7 \sim 30$ & 7.5YR4/6（褐色） & そしい & 乾 & 軟 \\
\hline & & 30 以深 & 7.5YR3/2（暗褐色） & 富む & 乾 & 堅 \\
\hline \multirow{3}{*}{$\begin{array}{l}\text { こもれびの森 } \\
\text { (武蔵野土壤) }\end{array}$} & 4,5 & $0 \sim 7$ & 10YR2/2（黒褐色） & 頗る富む & 潤 & しょう \\
\hline & & $7 \sim 40$ & 10YR2/2（黒褐色） & 頗る富む & 潤 & 軟 \\
\hline & & 40 以深 & 10YR3/1（黒褐色） & 富む & 潤 & 堅 \\
\hline
\end{tabular}




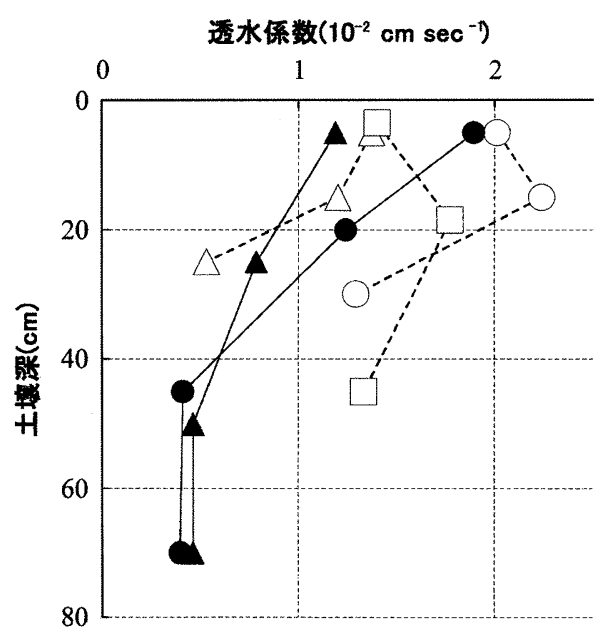

図-3 土壤の透水性

凡例は図-2 と同じ。

Fig. 3 Vertical changes in hydraulic conductivities of soil. Legends are the same as in Fig. 2.

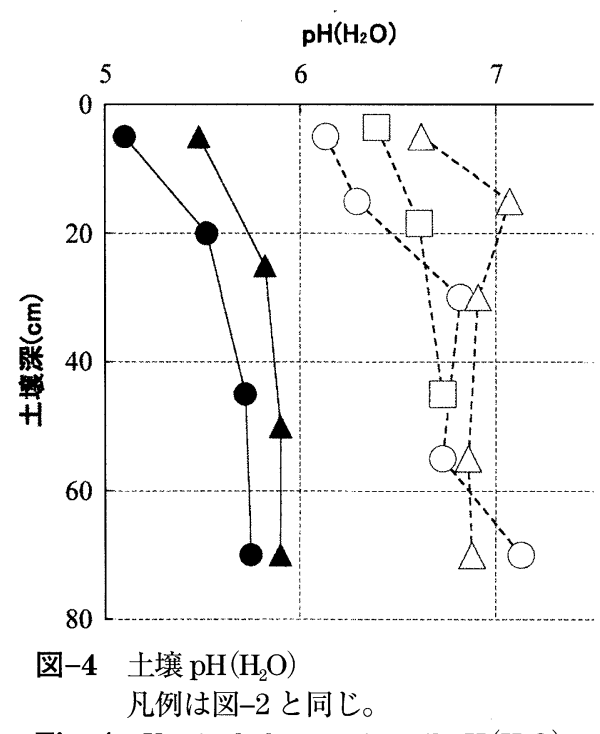

Fig. 4 Vertical changes in soil $\mathrm{pH}\left(\mathrm{H}_{2} \mathrm{O}\right)$. Legends are the same as in Fig. 2.

林の土壤 $\mathrm{pH}\left(\mathrm{H}_{2} \mathrm{O}\right)$ はいずれの土㙥墚でも武蔵野林よりもお よそ 1 高く, 6 以上であった。二の丸土壤の移植土壤におけ る $\mathrm{pH}\left(\mathrm{H}_{2} \mathrm{O}\right)$ の分布をみると（図-5)，林縁部に高い $\mathrm{pH}\left(\mathrm{H}_{2} \mathrm{O}\right)$ が分布している。二の丸雑木林と同様に，都市域の緑地で林 縁部の土壌 $\mathrm{pH}$ の上昇を辰巳 ${ }^{17)}$ も報告している。雨水のイオ

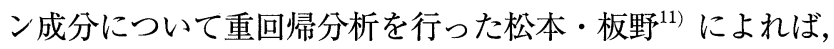
雨水の $\mathrm{H}^{+}$イオンを増加させる作用として働くイオン成分は $\mathrm{SO}_{4}^{2-}, \mathrm{NO}_{3}^{-}$であり, $\mathrm{H}^{+}$イオンを減少させる作用として働く イオン成分は $\mathrm{NH}_{4}^{+}, \mathrm{Ca}^{2+}$ である。また，東京都内の道路沿

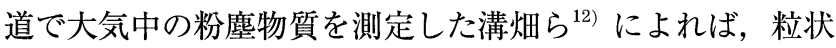
物質中の $\mathrm{Ca}^{2+}, \mathrm{NH}_{4}^{+}, \mathrm{NO}_{3}^{-}, \mathrm{SO}_{4}^{2-}$ の濃度はそれぞれ 5.45\%, 0.97\%，0.18\%，0.16\%であった。このように $\mathrm{H}^{+}$イオンを増加 させるイオンよりも減少させるイオンが多いことから，都市 部の道路で発生する粉塵には酸を中和する作用があると考え られる。真田ら ${ }^{15)}$ も都市域での大気からの降下粉塵による 降水の酸の中和を報告している。皇居内の二の丸雑木林の周 囲は車道になっているため，粉塵の吹き达みやすい林縁部で は，長期にわたる粉鹿等により移植土壤の酸が中和されたと 考えられる。富士見櫓〜富士見多聞にある樹林地の表層土 (土壤深 $0 \sim 10 \mathrm{~cm})$ の $\mathrm{pH}\left(\mathrm{H}_{2} \mathrm{O}\right)$ は $5.70 \pm 0.38$ であり, 二の 丸雑木林の移植土壤の $\mathrm{pH}\left(\mathrm{H}_{2} \mathrm{O}\right)$ よりも低い傾向にあった。

土壤の $\mathrm{C}, \mathrm{N}$ 濃度を図-6 に示す。土墒染 $0 \sim 10 \mathrm{~cm}$ の $\mathrm{C}$ 濃度は武蔵野土䁃で $130,170 \mathrm{~g} \mathrm{~kg}^{-1}$, 二の丸雑木林（移植土 壤) で $80 \sim 110 \mathrm{~g} \mathrm{~kg}^{-1}$ であった。土壤深 $0 \sim 10 \mathrm{~cm}$ の $\mathrm{N}$ 濃度 は武蔵野土壤では 7, $10 \mathrm{~g} \mathrm{~kg}^{-1}$, 二の丸雑木林 (移植土壌) で $5 \sim 7 \mathrm{~g} \mathrm{~kg}^{-1}$ であった。土壤深 $0 \sim 10 \mathrm{~cm}$ の $\mathrm{C} / \mathrm{N}$ 比は武蔵 野土壤, 二の丸雑木林 (移植土壤) のいずれでも $16 \sim 18$ で あった。二の丸雑木林の移植土壤の $\mathrm{C}, \mathrm{N}$ 濃度は武蔵野土壤 表層部よりも低い。この原因の一つとして，二の丸雑木林で は前述したような土壤 $\mathrm{pH}\left(\mathrm{H}_{2} \mathrm{O}\right)$ の中性化が微生物による有 機物分解（無機化）を促進させ，土㙥有機物量を減少させた

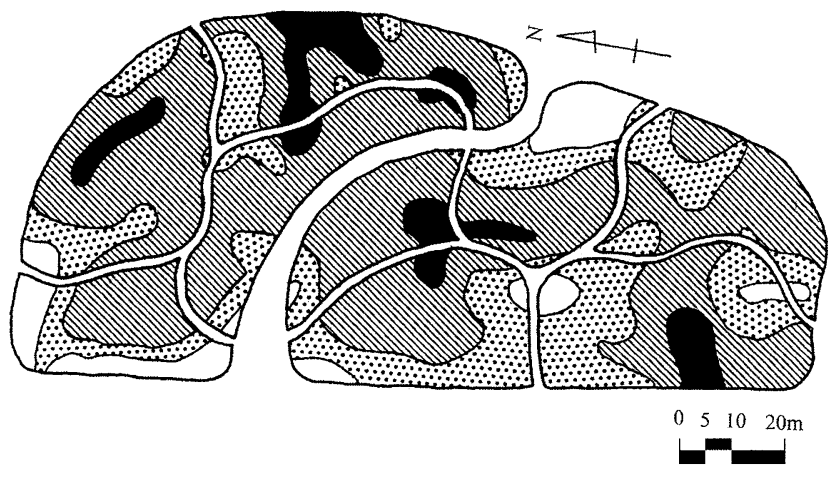

図-5二の丸雑木林の表層土壤（土壤深 $0 \sim 10 \mathrm{~cm} ）$ における $\mathrm{pH}\left(\mathrm{H}_{2} \mathrm{O}\right)$ の分布

Fig. 5 Distribution map of $\mathrm{pH}\left(\mathrm{H}_{2} \mathrm{O}\right)$ at soil depth $0-10 \mathrm{~cm}$ in the coppice forest on Ninomaru.

口 $\mathrm{pH}\left(\mathrm{H}_{2} \mathrm{O}\right) \leqq 6, \mathbb{Q}: 6<\mathrm{pH}\left(\mathrm{H}_{2} \mathrm{O}\right) \leqq 6.5$, : $: 6.5<$ $\mathrm{pH}\left(\mathrm{H}_{2} \mathrm{O}\right) \leqq 7, \square: 7<\mathrm{pH}\left(\mathrm{H}_{2} \mathrm{O}\right)$.

\section{ことが推察される。}

土壤中の交換性塩基濃度を図 -7 に示す。二の丸雑木林の 移植土壤の交換性 $\mathrm{Ca}$ は $12.1 \sim 16.2 \mathrm{cmol}(+) \mathrm{kg}^{-1}$ であり, 武 蔵野土㙵（土㙴深 $0 \sim 10 \mathrm{~cm})\left(3.6 \sim 4.5 \mathrm{cmol}(+) \mathrm{kg}^{-1}\right)$ よりも 多かった。また，二の丸雑木林の移植土壤の交換性 $\mathrm{Mg}$ は $1.4 \sim 2.5 \mathrm{cmol}(+) \mathrm{kg}^{-1}$ であり, 武蔵野土壤（土壤深 0 〜 $10 \mathrm{~cm})\left(1.1,1.2 \mathrm{cmol}(+) \mathrm{kg}^{-1}\right)$ より多かった。武蔵野林では, 二の丸雑木林に比べて $\mathrm{pH}$ の低い表層土壤（図-4）で交換性 $\mathrm{Ca}, \mathrm{Mg}$ が溶脱され，下層土壤に移動・集積されていると考 えられる。土䁃深 $0 \sim 10 \mathrm{~cm}$ までの交換性 $\mathrm{K}$ は武蔵野土壤と 二の丸雑木林の移植土㙵でそれぞれ $0.9,1.0$ と $0.7 \sim 1.4 \mathrm{cmol}$ (+) $\mathrm{kg}^{-1}$ であり, 大差なかった。 $\mathrm{K}$ は雨水によって植物体か ら溶脱されやすく，雨水による循環が落葉落枝による循環を 上回る元素である ${ }^{18)}$ 。交換性 $\mathrm{K}$ は二の丸土壤, 武蔵野土壤 

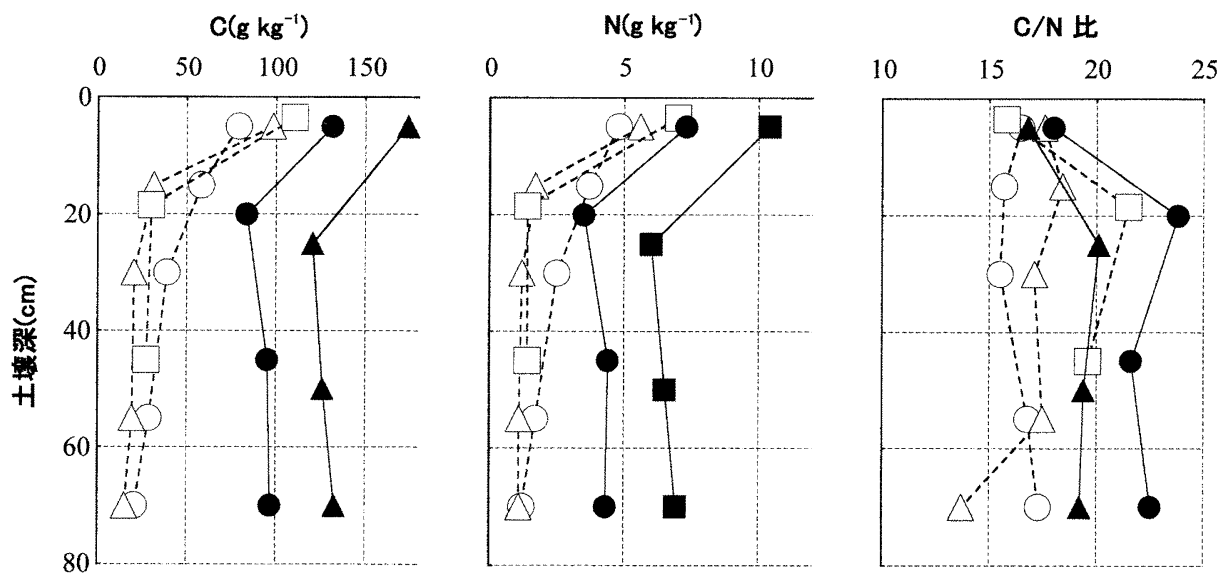

図-6 土壤の炭素 $(\mathrm{C}) \cdot$ 窒素 $(\mathrm{N})$ 濃度, $\mathrm{C} / \mathrm{N}$ 比 凡例は図 2 と同じ。

Fig. 6 Vertical changes in carbon concentration, nitrogen concentration and $\mathrm{C}: \mathrm{N}$ ratio. Legends are the same as in Fig. 2.
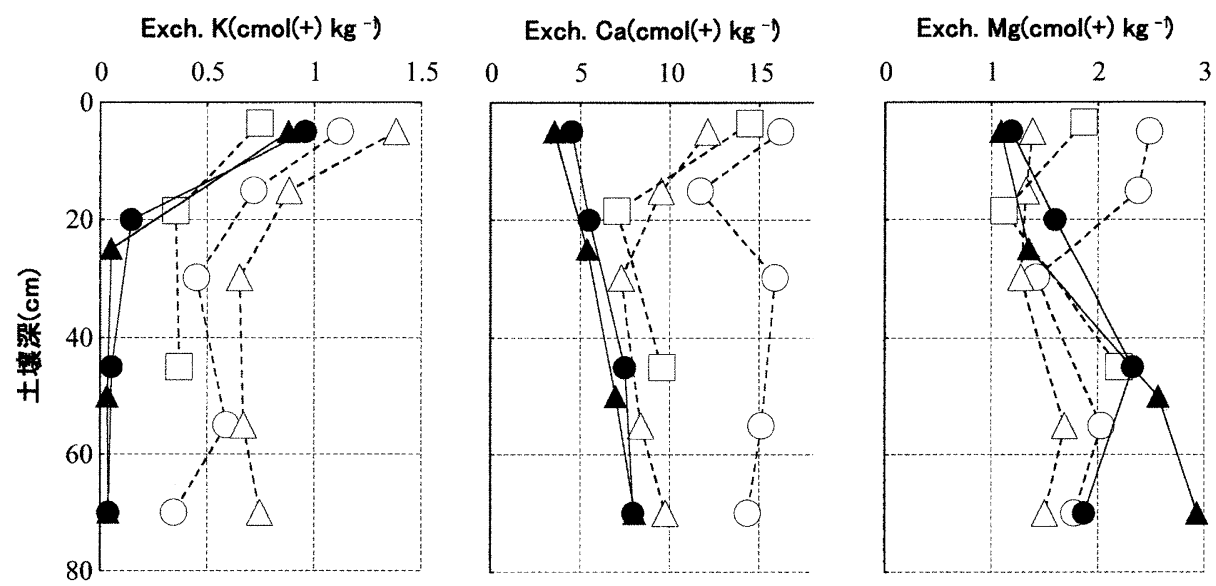

図-7 土䁃の交換性カリウム (Exch. K)，カルシウム (Exch. Ca)，マグネシウム (Exch. Mg) 濃度 凡例は図-2 と同じ。

Fig. 7 Vertical Changes in exchangeable potassium, exchangeable calcium and exchangeable magnesium concentrations. Legends are the same as in Fig. 2.

ともに表層より下層で少なかった。表層土壤では植物からの 溶脱によって K が供給されているため，交換性 K 濃度は高 い。しかし，交換性 $\mathrm{K}$ は交換性 $\mathrm{Ca}, \mathrm{Mg}$ よりも土䁃中の陽 イオン交換基に保持されにくいため ${ }^{19)}$, 武蔵野土壌の下層で は流亡により減少していると考えられる。二の丸雑木林周辺 の降雨に伴う $\mathrm{Ca}^{2+}$ 供給量 (湿性沈着量) は $740 \sim 760 \mathrm{~mol}(+)$ $\mathrm{ha}^{-1}$ year $^{-1}$ であり, $\mathrm{Mg}^{2+}\left(130 \sim 230 \mathrm{~mol}(+) \mathrm{ha}^{-1}\right.$ year $\left.^{-1}\right)$ や $\mathrm{K}^{+}$ $\left(19 \sim 44 \mathrm{~mol}(+) \mathrm{ha}^{-1} \mathrm{year}^{-1}\right)$ よりも多い4)。前述のように道 路で発生する粉塵には Ca が多く含まれる ${ }^{12)}$ 。また，自動車 による大気污染の程度を示す一月あたりの $\mathrm{NO}_{2}$ 濃度の $0.1 \mathrm{ppm}$ 超過時間数 (1978 年 12 月現在) は, 二の丸雑木林 のある東京都心で 120 時間, 武蔵野林のある相模原市で 20 時間以下であった ${ }^{13)}$ 。これらのことから, 二の丸雑木林では 武蔵野林に比べて道路粉塵による Ca 供給量が多いと推察さ れる。二の丸雑木林の移植土壤の交換性 Ca が武蔵野土壤よ
りも顕著に多くなった原因の一つとして，このような大気中 からの Ca 供給量の多さが考えられる。二の丸土壤では断面 間の交換性塩基濃度のばらつきが武蔵野土壤よりも大きく, 人工的につくられた土層の特徴である造成么ラによるもので あろう。

以上の結果をまとめると, 表土移植工法を用いて $10 \mathrm{~cm}$ 程度の表土を移植して造成した二の丸雑木林では, 造成後約 10 年経っても, 造成に伴って形成された土壤の層構造が保 たれていた。移植された土壤は水分状態を移植前と同様の植 物の生育に適した状態に保っていたが, $\mathrm{C}, \mathrm{N}$ 濃度を減少さ せて扔り, 土壤 $\mathrm{pH}\left(\mathrm{H}_{2} \mathrm{O}\right)$ と交換性塩基濃度を概ね増加させ ていた。

\section{5. おわりに}

表土移植工法の緑地造成法としての有効性について検討す 
るために, 皇居東御苑二の丸に表土移植工法によって造成さ れ, 約 10 年経過した雑木林と, 移植土溒採取地近くの雑木 林で土壤の理化学的性質を比較した。

本研究の結果から, 緑地の面積が小さい場合, 表土移植工 法によって森林土壤を都市緑地に移植しても周囲の影響で移 植土壤の性質は変化する。二の丸土壤の性質が武蔵野土壤と 大きく異なることから，二の丸雑木林の植生や土壤生物が武 蔵野林と異なった状態に変化していく可能性もあり, 今後の 調査が必要である。移植表土の有効性の維持や，土壌環境も 含めた雑木林の早期復元のために，今後，必要な造成地の面 積や周辺環境の影響について検討していく必要がある。

土壤養分特性の評価は土壤のみならず，目的物としての植 物の生育の面からも評価されるべきである。今後は植物の生 育状況や種組成の調査も行い，土壤養分特性との関連につい て検討し，表土移植工法の効果について総合的に評価する必 要があろう。

本研究を行うにあたり，現地でご指導いただいた宮内庁管 理部庭園課の渡辺忠明氏, 荻野久夫氏, 飛島雄史氏, 常冨 豊氏に厚くお礼申し上げる。

\section{引用文献}

1）相場芳憲（1992）森林土㙵，川名 明ら共著，造林学一三 訂版一, 朝倉書店, pp. 40-52.

2）番匠康夫（1989）生態系のリサイクル，亀山 章ら編，最 先端の緑化技術，ソフトサイエンス社，pp. 295-307.

3）土鎄盖分測定法委員会（1987）肥沃度測定のための土壌養 分分析法，養賢堂， $440 \mathrm{pp}$.

4）原宏（1992）降水，日本化学会編，陸水の化学，学会 出版センター, pp. 69-78.

5）長谷川秀三（1998）植栽基盤工，興水 肇・吉田博宣編，
緑を創る植栽基盤一その整㣁手法と適応事例一，ソフトサ イエンス社, pp. 98-105.

6）長谷川秀三・田畑 衛・小澤徹三・佐藤吉之（1984）重機 造成地の植栽基盤の物理性と活力度の関係について一高速 道路植栽地を例として一, 造園雑誌, 48(2)：104-122.

7）亀山 章 (1993) 都市緑地の計画, 井手久登・亀山 章編, ランドスケープ・エコロジー緑地生態学, 朝倉書店, pp. $52-64$.

8）亀山 章・作野由紀子・倉本 宣（1997）表土移植，日本 造園学会学会広報, 9(2): 24-25.

9）河田 弘（1976）土壤の理化学的性質の分析方法, 河田 弘 - 小島俊郎編, 環境測定法 $\mathrm{N}$ 一森林土壤一, 共立出版, pp. 79-92.

10）興水 肇（1987）客土と表土保全, 造園雑誌，51:27-34.

11）松本光弘 - 板野龍光 (1985) 雨水成分の統計的解析, 大気 污染学会誌, $20: 12-22$.

12）溝畑 朗・伊藤憲男・楠谷義和（2000）道路沿道に押ける 大気浮遊粒子状物質の物理的・化学的性質, 大気環境学会 誌, $35: 77-102$.

13）森口 實 -千秋鋭夫 - 小川 弘（1990）環境污染と気象一 大気環境アセスメントの技術一, 朝倉書店, $249 \mathrm{pp}$.

14）日本造園学会環境緑化工学研究委員会 (2000) 緑化事業に おける植裁基盤整備マニュアル，ランドスケープ研究， $63: 224-241$.

15）真田 勝・大友玲子・真田悦子（1994）札幌市羊ヶ丘にお ける過去 10 年間の降水の $\mathrm{pH}$ について, 日本林学会北海 道支部論文集, $42: 261-263$.

16）関口万有・冲中 健 ·沼達健一・太田清澄（1982）緑地工, 関口万有編著，造園工学，地球社，pp. 201-235.

17）辰已修三（1975）緑地環境機能論, 地球社, $274 \mathrm{pp}$.

18）堤 利夫（1987）森林の物質循環, 東京大学出版会, 124 pp.

19）和田信一郎（1997）土壤の化学性, 久馬一剛編, 最新土壤 学, 朝倉書店, pp. 73-95.

(2001.5.13 受理) 